Internal versus International Migration: Impacts of Remittances on Child Labor and Schooling in Vietnam

Michele Binci

Oxford Policy Management Ltd.

Gianna Claudia Giannelli

University of Florence

This paper focuses on the effects of domestic and international remittances on child labor and schooling. Using data from the 1992-1993 and 1997-1998 Vietnam Living Standards Surveys, we investigate school attendance and child labor in remittance recipient and nonrecipient households. The results of our binomial logit and two-sided censored regression panel analysis indicate that remittances increase schooling and reduce child labor. Although international remittances are found to have a stronger beneficial impact than domestic remittances in the cross-section, the panel analysis, taking account of fixed effects, reverses this result, showing that the only significant impact stems from domestic remittances.

\title{
INTRODUCTION
}

Remittances have risen enormously in recent decades, becoming a key source of external income for households of many developing countries. Remittances increase the well-being of receivers by easing consumption, investment, and the accumulation of human capital. Remittances can also have negative side effects, discouraging work of adults in receiving households and reducing care and supervision of children left behind.

While plenty of evidence is available on the role of international remittances for household decisions, less attention has been paid to 
domestic remittances. We aim at contributing to fill this gap. We focus on children, analyzing the impact of remittances on schooling and child labor of children left behind. We study Vietnam, using the panel data gathered in 1992-1993 and 1997-1998 Vietnam Living Standards Surveys (VLSS). The use of panel data allows us to overcome some of the common estimation problems encountered when studying migration and remittances. Our estimation strategy, based on the use of fixed-effects models, reveals some new features concerning the relative role of domestic and international remittances for household decisions.

The literature on the effects of remittances on household decisions is large and continuously growing. One of the main questions addressed, both theoretically and empirically, is whether remittances are spent more on consumption or more on investment in physical and human capital (Rapoport and Docquier 2006). In this field of research, the prominent role of remittances for investment on children's education has been assessed for several developing countries (Adams and Cuecuecha 2010, 2013). If remittances have a positive effect on children's education, they may also contribute to reduce child labor. From a theoretical point of view, the simplest way to incorporate remittances in a household model is to treat them as an additional income source. In this case, if parents' decision to rely on child labor is due to the necessity of meeting the most basic household needs and is not the result of a selfish attitude - namely if the "luxury axiom" holds (Basu and Van 1998) ${ }^{1}$ — an increase in income due to remittances is likely to release parents from the necessity of employing their children in family farm and/or business activities and/or sending them to work in the labor market. As for the effect on schooling, in a simple theory of allocation of child time, schooling and leisure are normal goods that jointly increase as income rises, leading to a reduction in child labor. In this sense, even if the relationship between child labor and schooling might become more complex, remittance inflows can play a role as extra income, with beneficial effects for children. This relationship also depends on the definition of child labor (if it includes, for example, domestic chores or not). The literature on the allocation of time within the households provides many theoretical and empirical examples where these two activities might be complementary (see, for a survey, Edmonds 2008).

${ }^{1}$ This axiom states that: "A family will send the children to the labor market only if the family's income from non-child labor sources drops very low." (Basu and Van 1998, 416). 
An increasing number of empirical findings seem to confirm the beneficial effects produced by remittances. Cox Edwards and Ureta (2003), for example, examine the effects of remittances from abroad on households' schooling decisions using data from El Salvador and find that remittances have a large significant effect on school retention. However, in another recent study on El Salvador, Acosta (2011) does not find a significant overall impact of remittances on schooling, when controlling for endogeneity. Yang (2008) finds that increased receipt of overseas remittances due to favorable exchange rate movements in the Philippines increases child schooling and educational expenditure, while reducing child labor. Dimova, Epstein, and Gang (2011), using Living Standards Measurement Survey data on the Kagera region in Tanzania, find empirical support for the hypothesis that both emigration and remittances reduce child labor. In a theoretical model of child labor, Epstein and Kahana (2008) show that the remittances sent by the emigrating parents might enable not only their children, but also others, to stop working.

With respect to the distinction between domestic and international remittances, the few studies undertaken so far show that international remittances tend to have a stronger impact than domestic remittances. Joseph and Plaza (2010), for Ghana, find that international remittances unambiguously reduce child labor while domestic remittances have no impact, and Antman (2012), for Mexico, find that paternal US migration significantly increases girls' schooling, while paternal domestic migration has no significant effect. In both papers, these results are interpreted as evidence that migrant parents are likely to be earning more if they have migrated abroad rather than internally, and, therefore, that remittances from international migration are more likely to improve child schooling outcomes.

At variance with these findings, a number of applied studies present less positive evidence on the relationship between migration and child well-being, highlighting the negative side effects of international migration. The study by Giannelli and Mangiavacchi (2010), for Albania, shows that parents' migration can have a negative effect on school attendance in the long term, mainly because of a lack of parental care for children left behind. Amuedo-Dorantes and Pozo (2010) find that, although remittances promote overall children's school attendance in the Dominican Republic, migration has a negative impact on the school attendance of children in migrant households. For Mexico, the evidence is mixed. 
The study by McKenzie and Rapoport (2011) reaches conclusions similar to the preceding paper for schooling of girls and boys in rural areas, while Antman (2012) finds a differential effect of father's absence, with no effect on boys, and a positive effect on girls.

In this paper, we define child labor and schooling as the proportion of children aged six to 15 in the household who do at least some work (paid or unpaid, for the family or for the market), and the proportion of children who are only engaged in schooling, respectively. We embrace the assumption, typical of the most part of the literature, that parents care about their children's education, spending some of their income and time supporting their children's school attendance and trying to avoid or limit child labor. Income and time become complementary factors in a child's well-being, with parents devoting time to looking after their children and considering how to spend money for them. Income from international remittances, instead, is hardly a complement of parental time for children left behind. Since parents who have migrated abroad normally have fewer opportunities to visit their families as compared to parents who have migrated internally, international migrants are likely to have less control on the use of remittances at home. As a consequence, international remittances may turn out to be less effective than domestic remittances in improving the well-being of children left behind. Hence, the distinction between domestic and international remittances may reveal that the positive effect of remittances on child well-being is counterbalanced by the negative effect of having distant parents who have migrated abroad. In this regard, Vietnam is a particularly suitable country for our analysis, since foreign migration is mostly directed toward the United States, quite a distant country in terms of both geographical location and culture.

From the methodological point of view, we deal with the problem of endogeneity due to unobservable characteristics by taking advantage of panel data. Panel data on international migration and remittances in developing countries are relatively rare. Of the 50 studies reviewed in Adams (2011), only five use panel household data.

To investigate the direction of the potential bias arising from omitted variables, we first perform a cross-sectional analysis. The results confirm previous cross-sectional evidence for other countries that international remittances have a positive and significant impact on children's welfare. However, in Vietnam this result is likely to be biased by the endogeneity of the migration decision, namely by specific unobserved 
factors associated with international migration, which are especially relevant in this country where migration has strong political roots. To tackle the problem of endogeneity, we use the two panel rounds and apply twosided censoring regression with fixed effects. This appears to be a sensible strategy, since the findings turn out to be reversed. In fact, controlling for time-invariant unobserved characteristics highlights the greater importance of domestic remittances for child labor and schooling, while international remittances become insignificant.

\section{THE CASE OF VIETNAM}

During the crucial decade of the 1990s, Vietnam experienced a sharp increase in economic growth rates and a dramatic drop in overall poverty (Dollar 2004) which yielded significant welfare gains for Vietnamese children (Edmonds and Turk 2004). At the same time, Vietnam's migration and remittance patterns reshaped and expanded, both internally and internationally (Nguyen 2009).

The beginning of this economic transformation can be roughly associated with the introduction of the Doi Moi policy in 1986, a plan of comprehensive economic innovations and liberalizations. Although these achievements varied significantly across households and regions, there were overall improvements in many economic and social indicators. The proportion of people living under the poverty line fell from over 50 percent in the early 1990s to 37 percent at the end of the decade (Glewwe, Koch, and Nguyen 2004), the prevalence of underweight children declined on average by 1.1 percent every year (Khan et al. 2007), and child labor declined and school enrollment rates increased (Nguyen 2009).

Evidence shows that migration patterns played a central role in Vietnam's development, with the flow of remittances increasing in quantity and changing in terms of provenance. After the collapse of the Soviet Union, different areas of the world were chosen by Vietnamese emigrants as new destinations, including Asia, the Middle East, and especially the United States. The large flow of migrants toward the United States has its roots in the effective migration network created by a large community of Vietnamese immigrants, who started to settle down there in 1975, when, at the end of the Vietnam War, many people who had worked closely with the Americans fled the new Socialist regime for fears of reprisals. For these reasons, even if international migration in the 1990s was substantially driven by economic pull factors, its origins were mainly political. 
Remittances from North America increased from around 40 percent of total remittances at the beginning of the 1990s to almost 60 percent in 1998. The expansion of the flow of Vietnamese emigrants to Arab and Asian non-traditional markets also reflected the new Vietnamese "opendoor" approach, which led to the creation of the Department for Overseas Labor Management, in order to facilitate, implement, and supervise labor export agreements with overseas markets.

Evidence shows that the remittance inflows also became more stable, outstripped the Official Development Assistance (ODA), and almost matched the Foreign Direct Investment (FDI) flows, as the main and most reliable source of foreign financial inflow for the country. However, as will be shown in the next section, in the same decade the flow of domestic remittances also increased considerably.

One of the most positive outcomes of the socioeconomic transition undertaken by Vietnam in the 1990s was an impressive reduction in the participation of children in the national labor force, coupled with a dramatic increase in their school enrollment rates. Although in that decade the improvements were particularly impressive, universal primary education has always been one of the main concerns of the Socialist Republic of Vietnam since the very first years of independence and the political and ideological commitment of the socialist government had enabled the country to reach a proportion of 86 percent of children officially attending primary school by 1990 (Edmonds and Turk 2004). In 1991, the government also issued a new law, specifically aimed at reinforcing this positive trend, the Law on the Universalization of Education. Additionally, in the revised Constitution of 1992, a strong emphasis was placed on primary education, defined as "both free and compulsory."

\section{DATA AND EMPIRICAL STRATEGY}

We use the first two waves of the VLSS, conducted by the General Statistics Office of Vietnam, in the framework of the World Bank's Household Living Standards Measurement Surveys. The data for the first VLSS were collected from October 1992 to October 1993 and covered 4,800 households, 
while the second round was undertaken from December 1997 to December 1998 with a sample of 6,002 households of which 4,305 were also interviewed in 1992-1993 (World Bank 2000, 2001). ${ }^{2}$ We focus on the rates of school attendance and on the incidence of child labor among children aged six to 15 and perform both cross-sectional and panel analyses.

We select, for our purposes, the households that have at least one child aged six to 15 and that provide us with the relevant information on child schooling and labor. These include 2,930 households in 1993 and 2,739 households in 1998, respectively. We select from the panel 2,054 households, those with children in the chosen age range in both years. We conduct our cross-sectional and panel analyses on the sample of panel households.

Table 1 shows an increase in the percentage of households receiving remittances over the 1990s. Domestic remittances reach a much larger number of families, compared to international remittances, but the value of international remittance inflows is far higher. However, the share of the value of domestic remittances increases by 10 percentage points from 1993 to 1998.

Table 2 shows a sharp rise in the proportion of children only going to school, coupled with a decline in the proportion of children only working. Girls work more than boys, but we observe a noticeable reduction in gender differences, especially among children only working.

Gender differences, however, may arise because of a "sibling effect," according to which the probability of working or going to school of a child may depend on gender and work/schooling of either an older or younger sibling. For example, Edmonds (2006) finds for Nepal that, at the modal birth spacing, the younger girl works more than her older brother.

Table 3 gives some insight into this issue for Vietnam. In household with mixed-gender school-age children, oldest children of either gender always have a higher (lower) probability of working (schooling) than the next oldest siblings, and females always have a higher (lower) probability of working (schooling), irrespective of the number of children in the household. The number of children in the household, however, contributes to increase (reduce) the probability of work (schooling). So it

\footnotetext{
${ }^{2}$ We were not able to use the 2002 and 2004 rounds of the survey since the information on migration and remittances is substantially reduced and changed. For data consistency, we were therefore forced to limit the analysis to 1993 and 1998.
} 
TABLE 1

Percentage of Households Receiving Remittances and Distribution of Total Value between Domestic and International RemitTances

\begin{tabular}{lccccc}
\hline \hline & \multicolumn{2}{c}{ Percent of households } & & \multicolumn{2}{c}{ Percent of total value } \\
\cline { 2 - 3 } \cline { 5 - 6 } Source of remittances & 1993 & 1998 & & 1993 & 1998 \\
\hline Domestic remittances & 13.5 & 14.6 & 30 & 40 \\
International remittances & 3.8 & 4.2 & & 70 & 60 \\
\hline
\end{tabular}

Note: calculated on 2,054 panel households.

Source: VLSS 1993 and 1998.

TABLE 2

Activities of Children Aged 6-15 by Gender (\%)

\begin{tabular}{lccccc}
\hline \hline & \multicolumn{2}{c}{ Boys } & & \multicolumn{2}{c}{ Girls } \\
\cline { 2 - 3 } \cline { 5 - 6 } Child activities & 1993 & 1998 & & 1993 & 1998 \\
\hline School only & 58 & 74 & 55 & 73 \\
Work and school & 22 & 16 & 19 & 14 \\
Work only & 11 & 6 & 16 & 8 \\
Neither school nor work & 9 & 4 & 10 & 5 \\
\hline
\end{tabular}

Note: calculated on the children of the panel households of the 1993 and 1998 surveys.

Source: VLSS 1993 and 1998.

seems that, for Vietnam, we should expect age, gender, and number of school-age children in the household to separately affect children's activities, while the gender-birth spacing order may not represent a relevant issue.

Our dependent variables are the household rates of children's school attendance and child labor, since we have chosen to conduct our analysis at the household level. This choice, while on the one hand, has the

TABLE 3

Schooling and Labor of a Child Living in Households with Mixed-Gender School-Age SIBLINGS, $1998(\%)$

\begin{tabular}{|c|c|c|c|c|c|c|}
\hline & \multicolumn{2}{|c|}{$\begin{array}{l}\text { Two-children } \\
\text { households }\end{array}$} & \multicolumn{2}{|c|}{$\begin{array}{l}\text { Three-children } \\
\text { households* }\end{array}$} & \multicolumn{2}{|c|}{$\begin{array}{l}\text { Three plus-children } \\
\text { households* }\end{array}$} \\
\hline & $\begin{array}{l}\text { Oldest is } \\
\text { male }\end{array}$ & $\begin{array}{l}\text { Oldest is } \\
\text { female }\end{array}$ & $\begin{array}{l}\text { Oldest is } \\
\text { male }\end{array}$ & $\begin{array}{l}\text { Oldest is } \\
\text { female }\end{array}$ & $\begin{array}{l}\text { Oldest is } \\
\text { male }\end{array}$ & $\begin{array}{l}\text { Oldest is } \\
\text { female }\end{array}$ \\
\hline $\begin{array}{l}\text { Schooling of } \\
\text { oldest sibling }\end{array}$ & 72 & 65 & 53 & 53 & 51 & 46 \\
\hline $\begin{array}{l}\text { Schooling of next } \\
\text { oldest sibling }\end{array}$ & 82 & 87 & 76 & 81 & 71 & 74 \\
\hline $\begin{array}{l}\text { Child labor of } \\
\text { oldest sibling }\end{array}$ & 23 & 31 & 43 & 40 & 45 & 46 \\
\hline $\begin{array}{l}\text { Child labor of next } \\
\text { oldest sibling }\end{array}$ & 11 & 10 & 21 & 17 & 25 & 22 \\
\hline $\begin{array}{l}\text { Number of } \\
\text { children }\end{array}$ & 652 & 664 & 316 & 324 & 414 & 454 \\
\hline
\end{tabular}

${ }^{*}$ Only cases where the second oldest is of different gender with respect to the first. 
disadvantage of leading to a loss of child-specific information, on the other hand has the advantage of allowing us to sample all panel households with children in the selected school-age range. If we had chosen to conduct a child-specific analysis, given the time distance between the two surveys, our sample would have been severely constrained by the limited number of panel children who remain in the school-age range in both rounds of the survey. In fact, in the five-year span between the two surveys, the most part of children present in 1993 would have become older than 15, thus dropping out of our sample. For similar reasons, Edmonds (2005) follows the same strategy. Moreover, since a sibling effect does not seem to arise in Vietnam, the loss of information on birth order, implied by the choice to conduct the analysis at the household level, should not represent a problem here.

Our definitions of Child Labor and Schooling are taken from the sections dedicated to employment and education, respectively, in the 1993 and 1998 VLSS questionnaires. We consider a child as engaging in labor if they answered "yes" to at least one of the three questions related to "employment during the past seven days," specifically: "have you worked for pay for someone not a member of your household?"; "did you work in a field [...] or raise livestock [...] or process home-produced crops for your household?"; and "have you worked in a business managed by yourself or by your household?" As far as schooling is concerned, we consider a child as only going to school if they answered "yes" to the question "are you currently attending school?" (including those on summer breaks) and "no" to all of the above questions on employment.

More precisely, in our econometric model for each household $i$ :

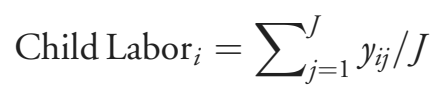

where the $j$ index refers to the $j$ th child in the household, $J$ is the total number of children aged six to 15 in household $i$, and $y_{i j}=1$ if child $j$ does any form of work in agriculture, in the household business, or in the labor market for a wage, notwithstanding the fact that she/he might also be attending school. It follows that $0 \leq$ Child Labor $\leq 1$ for each family $i$. The other dependent variable, Schooling, is calculated in an analogous way. It equals one when all children in the household go to school and do not perform any kind of work and zero when no child is only going to school without being engaged in some form of labor. Finally, $0<$ Schooling $\leq 1$ if at least one child is attending school without working. 
According to our definition, therefore, Child Labor/Schooling are the probabilities of child labor/school attendance within the household.

The econometric specification for the cross section is the following:

$$
\begin{gathered}
\text { Child Labor }_{i}=\alpha+\beta X_{i}+\gamma\left(\sum_{j} z_{i j} / J\right)+\varepsilon_{i} \\
\text { Schooling }_{i}=\delta+\eta X_{i}+\phi\left(\sum_{j} z_{i j} / J\right)+\eta_{i}
\end{gathered}
$$

where $X_{i}$ are household's characteristics and $z_{i j}$ are household $i$ children's characteristics, $\varepsilon$ and $\eta$ are random error terms.

In the panel analysis, we take advantage of the longitudinal nature of the data by estimating the following fixed-effects models:

$$
\text { Child Labor }_{i t}=\alpha+\theta_{i}+\beta X_{i t}+\gamma\left(\sum_{j} z_{i j t} / J\right)+\chi_{i t}
$$

and

$$
\text { Schooling }_{i t}=\delta+\omega_{i}+\eta X_{i t}+\phi\left(\sum_{j} z_{i j t} / J\right)+\xi_{i t}
$$

where $t$ denotes time, $\theta_{i}$ and $\omega_{i}$ are the unobservable household fixed effects and $\chi_{i t}$ and $\xi_{i t}$ are the remainder disturbance terms.

With proportions as dependent variables, we need to estimate the models with nonlinear techniques. We apply two estimation techniques that allow us to compare the cross-sectional and the panel results, since they are both tailored to deal with proportions as dependent variables. For the cross section, a suitable model is the binomial logit, an estimation method for grouped data, where, for each household, the dependent variable is split into two variables, namely the number of children who work/attend school and the number of children aged six to 15 living in the household. ${ }^{3}$

With panel data, we apply a two-sided censored regression with fixed effects (Alan et al. 2014). Alan et al. (2014) formulate the two-sided censored regression model as observations of $(Y ; x ; L ; U)$ from the model:

\footnotetext{
${ }^{3}$ This amounts to estimate a maximum-likelihood logit model on "grouped" data. The estimation has been performed using the "blogit" command in the STATA software.
} 


$$
Y_{i t}^{*}=x_{i t}^{\prime} \beta+\varepsilon_{i t}
$$

where $Y^{*}$ is unobserved but we observe:

$$
Y_{i t}=\left\{\begin{array}{l}
0 \quad \text { if } \quad Y_{i t}^{*}<0 \\
Y_{i t}^{*} \quad 0 \leq Y_{i t}^{*} \leq 1 \\
1 \quad \text { if } \quad Y_{i t}^{*}>1
\end{array}\right.
$$

and $\beta$ is the parameter of interest. When $Y$ is a share, $L$ and $U$ will typically be 0 and 1 , respectively.

This estimation technique starts with a comparison of two observations for a given individual in a panel, and then constructs recensored residuals on which moment conditions are based to identify the parameters of interest (Honoré and Powell 1994). ${ }^{4}$

The vector $X_{i}$ of household variables contains the two explanatory variables of interest, namely the logarithm of the value of domestic remittances and the logarithm of the value of international remittances, both of them measured at the household level $i$. They are the logarithm of the amount of money (in Vietnamese Dongs) received by each household from members who have left the household to migrate. Remittances are defined in a special section" on "income from remittances" in both the 1993 and 1998 VLSS questionnaires as "the amount of money and monetary value of in-kind benefits received by a household from people not living in the household, including family and friends, which do not require repayment." A question about the place of residence of the remitter (either "province in Vietnam" or "abroad") allows us to distinguish between internal and international remittances. The summary statistics of our two dependent variables and of all explanatory variables are presented in Table 4.

The first two figures in Table 4 show the average household incidence of child labor and school attendance. In 1993, in each household on average 64 percent of children were only going to school, while 25 percent of them were either studying and working or only

\footnotetext{
${ }^{4}$ See pages 6-7, equations 3-5, of Alan et al. (2014) for an intuition of this method. The estimation has been performed using the "two-side" STATA routine which calculates the estimator developed in Alan et al. 2014. (http://www.princeton.edu/-honore/stata/ index.html\#1._Pantob_version_0.6).

${ }^{5}$ See Section 13, part a, of the questionnaire.
} 
TABLE 4

Summary Statistics: Child Labor, Child Schooling, Remittances, and Other Control Variables in Households with Children Aged 6-15

\begin{tabular}{|c|c|c|c|c|}
\hline \multirow[b]{2}{*}{ Variables } & \multicolumn{2}{|c|}{ Mean } & \multicolumn{2}{|c|}{$\begin{array}{l}\text { Standard } \\
\text { deviation }\end{array}$} \\
\hline & 1993 & 1998 & 1993 & 1998 \\
\hline \multicolumn{5}{|l|}{ Dependent variables } \\
\hline Child Labor (proportion of working children) & 0.25 & 0.25 & 0.34 & 0.37 \\
\hline Schooling (proportion of children attending school) & 0.64 & 0.58 & 0.39 & 0.48 \\
\hline \multicolumn{5}{|l|}{ Explanatory Variables } \\
\hline Log of the value of domestic remittances* & -8.17 & -7.99 & 2.69 & 3.07 \\
\hline Log of the value of international remittances* & -8.87 & -8.77 & 1.77 & 2.10 \\
\hline Proportion of male children in the household & 0.51 & 0.52 & 0.38 & 0.38 \\
\hline Average age of children in the household & 9.57 & 11.67 & 2.01 & 1.95 \\
\hline Recipient is migrant's parent or grandparent & 0.03 & 0.05 & 0.16 & 0.21 \\
\hline Gender of the household head ( 1 is male) & 0.81 & 0.80 & 0.39 & 0.40 \\
\hline Household head: low level of education & 0.37 & 0.26 & 0.48 & 0.44 \\
\hline Household head: medium level of education & 0.10 & 0.48 & 0.30 & 0.50 \\
\hline Household head: high level of education & 0.06 & 0.20 & 0.24 & 0.40 \\
\hline Household head: age $30-50$ years & 0.37 & 0.73 & 0.48 & 0.44 \\
\hline Household head: age over 50 years & 0.08 & 0.26 & 0.27 & 0.44 \\
\hline Size of the household & 5.97 & 5.70 & 1.96 & 1.81 \\
\hline Number of children in the household & 2.27 & 2.14 & 1.07 & 1.05 \\
\hline Urban household & 0.17 & 0.19 & 0.37 & 0.39 \\
\hline Expenditure quintile 2 & 0.23 & 0.21 & 0.42 & 0.41 \\
\hline Expenditure quintile 3 & 0.20 & 0.21 & 0.40 & 0.41 \\
\hline Expenditure quintile 4 & 0.18 & 0.20 & 0.38 & 0.40 \\
\hline Expenditure quintile 5 (top) & 0.16 & 0.17 & 0.37 & 0.38 \\
\hline Number of Observations: & \multicolumn{2}{|c|}{2,054} & \multicolumn{2}{|c|}{2,054} \\
\hline
\end{tabular}

*Through the transformation formula employed to generate the logarithms, all amounts equaling zero were replaced by a (very small) negative number. The means shown in include both recipients and non-recipient households and this explains their negative values.

working. In 1998, the proportion of children engaged in some form of labor is practically the same, but the average proportion of children only going to school declines to 58 percent. This could be due to the fact that, in our 1998 sample, there are fewer children of primary school age (who are generally more likely to only go to school) compared to the 1993 sample. These proportions may change because of the change in children's age between the first and second wave. In fact, the Average age of children in the household increases from 9.57 years in 1993 to 11.67 years in 1998, thus overcoming the threshold at which Vietnamese children finish primary school (in Vietnam, primary school starts at six years of age and lasts five years). This detectable effect of the increase in children's average age highlights the substantial length of time, five years, that passed between these two rounds of the VLSS. 
Therefore, controlling for children's average age should tackle the problem of aging in the panel analysis.

The rest of the summary statistics associated with children show the figures emerging from our choice of averaging the child's profile. In particular, since we are employing the household average values of children's characteristics, age is represented by the Average age of children in the household and gender by the Proportion of males in the household. Besides the dummy variable associated with the gender of the household head, we are using "level of education" and "age group" of the household head, which are expressed by three dummies and two dummies, respectively. The reference base for education is "no qualification obtained" and the three levels represent primary school (low education), secondary school (medium), and college or university (high). For the age group, the reference base is "under 30 years of age." Using these age cohorts instead of a continuous age variable allows us to distinguish between relatively younger and older households heads, which are likely to have specific attitudes toward children.

The number of children in the household and household size are two other crucial variables included in the analysis. ${ }^{6}$

Another dummy captures the urban/rural location of the household. As a measure of household wealth, we are employing the VLSS expenditure data, sorted into five quintile ranks, through the use of four dummy variables (first poorest quintile as reference). Although it would have been more valuable for our analysis to use a measure of total household income, given its influence on child labor and schooling (see for example De Carvalho Filho 2012), there is no such information in the 1993 and 1998 VLSS datasets.

Also at variance with other studies, the data allow us to control for whether or not the people who received the remittances were the migrants' parents or grandparents, thus relatively older members of the household. The presence of this variable enriches the pool of information on remittances in our model. In a preliminary analysis, we have also tested out some alternative remittance variables, exploiting the wealth of

\footnotetext{
${ }^{6}$ In a preliminary analysis, we had also included the variable "dependency ratio" (ratio of adults over 60 plus children below 15 divided by total number of household members), since the number of dependents may affect the amount of remittances and indirectly impact child schooling/labor decisions. We do not include it here since it turned out not to be significant (except for a negative coefficient for schooling in 1998 which is significant at 10 percent).
} 
data in the VLSS surveys. For instance, we find no significant impacts on child labor and schooling associated with women receiving larger shares of remittances.

Taking advantage of the information on the place of residence, we also control for clustered standard errors at the village level.

\section{RESULTS}

The descriptive evidence we have just discussed seems to indicate a general improvement of children's welfare in the period studied. In the next section, we present the results of our test on whether a positive correlation exists between these improvements and the simultaneous presence of remittances.

In this section, we present the results of the cross-sectional and panel analyses.

\section{Cross-Sectional Results}

Table 5, which shows the results of the binomial logit regressions separately for 1993 and 1998, suggests that remittances played some part in reducing Child Labor, in both 1993 and 1998.

The coefficients of the logarithms have a negative sign, as expected: Children are less likely to be engaged in labor activities if their household is a recipient of remittances. However, the level of statistical significance is very low for all coefficients apart from the international remittance one in 1998. Domestic remittances do not seem to play a substantial role, being insignificant in both years. Also note that our additional remittance variable, which controls for the migrant's relationship with the recipient of remittances in the household, is insignificant.

From the examination of the other explanatory variables, we notice that, in both years, older children and children living in rural areas were more likely to work. We also notice that while an increasing overall size of the household reduced the child's probability to work, with older members available to work, a higher number of children in the household caused a rise in child labor, especially in 1993. As for the gender aspects, in 1993 the higher the Proportion of males in the household, the lower the probability of Child Labor, while in 1998 this coefficient is not significant.

We have also estimated the model pooling the two cross sections. The coefficient of the dummy Year (equal to one in 1998 and to zero in 
TABLE 5

Household Child Labor in 1993 and 1998. Binomial Logit Estimates

\begin{tabular}{|c|c|c|c|}
\hline & $\begin{array}{c}(1) \\
1993 \\
\text { Coefficients (SE) }\end{array}$ & $\begin{array}{c}(2) \\
1998 \\
\text { Coefficients (SE) }\end{array}$ & $\begin{array}{c}(3) \\
\text { Pooled sample } \\
\text { Coefficients (SE) }\end{array}$ \\
\hline $\begin{array}{l}\text { Log of the value of domestic } \\
\text { remittances }\end{array}$ & $-0.0175(0.0198)$ & $-0.0103(0.018)$ & $-0.0138(0.0137)$ \\
\hline $\begin{array}{l}\text { Log of the value of } \\
\text { international remittances }\end{array}$ & $-0.0308(0.0286)$ & $-0.0896^{* * *}(0.0317)$ & $-0.0642^{* * *}(0.210)$ \\
\hline $\begin{array}{l}\text { Proportion of male children } \\
\text { in the household }\end{array}$ & $-0.2834^{* *}(0.1296)$ & $-0.1585(0.1423)$ & $-0.2169^{* *}(0.0999)$ \\
\hline $\begin{array}{l}\text { Average age of children in the } \\
\text { household }\end{array}$ & $0.9642^{* * *}(0.2135)$ & $0.9949^{* * *}(0.3166)$ & $0.9525^{* * *}(0.1514)$ \\
\hline $\begin{array}{l}\text { Average age of children in the } \\
\text { household squared }\end{array}$ & $-0.0273^{* * *}(0.0102)$ & $-0.0270^{* *}(0.0136)$ & $-0.0260^{* * *}(0.0068)$ \\
\hline $\begin{array}{l}\text { Recipient is migrant's parent } \\
\text { or grandparent }\end{array}$ & $0.0385(0.3469)$ & $-0.0863(0.2749)$ & $-0.0188(0.02166)$ \\
\hline $\begin{array}{l}\text { Gender of the household } \\
\text { head }\end{array}$ & $-0.0303(0.1316)$ & $0.0143(0.1503)$ & $-0.0191(0.1098)$ \\
\hline $\begin{array}{l}\text { Household head: low level of } \\
\text { education }\end{array}$ & $0.0529(0.0976)$ & $-0.0844(0.1732)$ & $0.0311(0.8734)$ \\
\hline $\begin{array}{l}\text { Household head: medium } \\
\text { level of education }\end{array}$ & $0.4503^{* * *}(0.1403)$ & $0.0284(0.1931)$ & $0.1916^{*}(0.1159)$ \\
\hline $\begin{array}{l}\text { Household head: high level of } \\
\text { education }\end{array}$ & $-0.0186(0.2040)$ & $0.1733(0.2180)$ & $0.1800(0.1451)$ \\
\hline $\begin{array}{l}\text { Household head: age } 30- \\
50 \text { years }\end{array}$ & $-0.0257(0.0849)$ & $-0.4145(0.4461)$ & $-0.0595(0.0849)$ \\
\hline $\begin{array}{l}\text { Household head: age over } \\
50 \text { years }\end{array}$ & $-0.0297(0.2082)$ & $-0.4913(0.4543)$ & $-0.0944(0.1342)$ \\
\hline Size of the household & $-0.0836^{* * *}(0.0305)$ & $-0.0716^{* *}(0.0366)$ & $-0.0771^{* * *}(0.0255)$ \\
\hline $\begin{array}{l}\text { Number of children in the } \\
\text { household }\end{array}$ & $0.1293^{* *}(0.0585)$ & $0.0957^{* *}(0.0497)$ & $0.1091^{* * *}(0.0396)$ \\
\hline Urban household & $-0.9111^{* * *}(0.2253)$ & $-1.2340^{* * *}(0.2708)$ & $-1.0593^{* * *}(0.2053)$ \\
\hline Expenditure quintile 2 & $-0.0736(0.1170)$ & $-0.4078^{* * *}(0.1249)$ & $-0.2351^{* * *}(0.0883)$ \\
\hline Expenditure quintile 3 & $-0.3470^{* * *}(0.1260)$ & $-0.6124^{* * *}(0.1499)$ & $-0.4720^{* * *}(0.1000)$ \\
\hline Expenditure quintile 4 & $-0.8192^{* * *}(0.1297)$ & $-1.1035^{* * *}(0.1611)$ & $-0.9534^{* * *}(0.1080)$ \\
\hline Expenditure quintile 5 (top) & $-1.1508^{* * *}(0.1700)$ & $-1.8281^{* * *}(0.2476)$ & $-1.4320^{* * *}(0.1498)$ \\
\hline Year $(1998=1)$ & - & - & $-0.8719^{* * *}(0.1173)$ \\
\hline $\begin{array}{l}\text { Number of Observations: } \\
2,054 \text { households }\end{array}$ & 4,659 children & 4,395 children & 9,054 children \\
\hline$R^{2}$ & 0.1064 & 0.1108 & 0.1064 \\
\hline
\end{tabular}

Notes: Equality of coefficient between 1993 and 1998 is rejected for: Expenditure quintile 2 (coeff. -0.34 ; SE: $0.17 ; t:-2.07)$ and Expenditure quintile 5 (top): coeff. -0.69 ; SE: $0.28 ; t:-2.42$.

Significance levels $=* * *(p<0.01), * *(p<0.05), *(p<0.1)$. Cluster-Robust Standard Errors in brackets.

1993) in column (3), capturing the effect of some fixed determinants that are unspecified in the model, shows that in 1998 it was significantly less probable that children were engaged in child labor. To test for equality of specific coefficients between 1993 and 1998, we have estimated the pooled model also including all interactions with the dummy Year. The only fully significant (and negative) coefficients that reject the hypothesis of equality 
of coefficients in the two years are those of the interactions with the bottom and top quintiles of expenditure. This evidence shows that, while moving from lower to higher expenditure quintiles reduced the probability of working in the two years, in 1993 the passage from the bottom quintile to the second does not have a significant impact. We have shown that people in the lowest quintile were poorer in 1993 than in 1998 and this is confirmed by our results, which seem to highlight a general improvement of the economic situation.

As for Schooling (see Table 6), only the coefficient of the logarithm of international remittances for 1998 is positive and statistically significant, indicating that only international remittances have an impact on children's school attendance. Our additional remittance variable concerning the recipient's relationship with the migrant member is not significant.

From the analysis of the other control variables, it emerges that the urban/rural difference reflects the patterns noticed in the child labor estimation, with children in rural areas still clearly worse off in both years. Finally, as expected, belonging to a household in higher expenditure quintiles increased the children's probability to go to school in the two years observed. As for gender, males have a higher probability of schooling in 1993. The number of children in the household has a negative and highly significant coefficient in both years. Moreover, the test for equality of specific coefficients between 1993 and 1998 shows that Number of children in the household has a significantly more negative coefficient in 1998. The detrimental effect of a high number of school-age children in the household, already appearing at a descriptive level (see Table 3), is therefore confirmed by the cross-sectional analysis.

\section{Panel Results}

Despite the presence of numerous control variables, the use of cross-sectional data runs the risk of omitted variable bias in the estimated coefficients relating to remittances. As previously discussed, in Vietnam the decision to migrate toward the United States has its roots in political factors. The migration flow started at the time of the Vietnam war for political reasons has contributed to create a migration network among the subsequent generations of Vietnamese households. Since the VLSS survey does not contain information on migration networks, the problem of unobserved variables that bias the estimates may arise. Panel data estimation 
TABLE 6

Household Child Schooling in 1993 and 1998. Binomial Logit Estimates

\begin{tabular}{|c|c|c|c|}
\hline & $\begin{array}{c}(1) \\
1993 \\
\text { Coefficients (SE) }\end{array}$ & $\begin{array}{c}(2) \\
1998 \\
\text { Coefficients (SE) }\end{array}$ & $\begin{array}{c}\text { (3) } \\
\text { Pooled sample } \\
\text { Coefficients (SE) }\end{array}$ \\
\hline $\begin{array}{l}\text { Log of the value of domestic } \\
\text { remittances }\end{array}$ & $0.0167(0.0175)$ & $0.0245(0.0211)$ & $0.0194(0.0146)$ \\
\hline $\begin{array}{l}\text { Log of the value of } \\
\text { international remittances }\end{array}$ & $0.0454(0.0278)$ & $0.0988^{* * *}(0.0338)$ & $0.0740^{* * *}(0.0215)$ \\
\hline $\begin{array}{l}\text { Proportion of male children } \\
\text { in the household }\end{array}$ & $0.1965^{*}(0.1187)$ & $0.0334(0.1634)$ & $0.1352(0.1030)$ \\
\hline $\begin{array}{l}\text { Average age of children in the } \\
\text { household }\end{array}$ & $0.4596^{* *}(0.2077)$ & $-1.1229^{* *}(0.4943)$ & $-0.2516(0.1724)$ \\
\hline $\begin{array}{l}\text { Average age of children in the } \\
\text { household squared }\end{array}$ & $-0.0361^{* * *}(0.0102)$ & $0.0343(0.0212)$ & $-0.0008(0.0078)$ \\
\hline $\begin{array}{l}\text { Recipient is migrant's parent } \\
\text { or grandparent }\end{array}$ & $-0.2278(0.3121)$ & $0.2473(0.3602)$ & $0.0787(0.2499)$ \\
\hline Gender of the household head & $-0.0722(0.1174)$ & $-0.02151(0.1682)$ & $-0.0698(0.1116)$ \\
\hline $\begin{array}{l}\text { Household head: low level of } \\
\text { education }\end{array}$ & $0.0397(0.0878)$ & $0.212(0.2877)$ & $0.0173(0.0748)$ \\
\hline $\begin{array}{l}\text { Household head: medium } \\
\text { level of education }\end{array}$ & $0.0120(0.1300)$ & $0.4528(0.2926)$ & $0.2202(0.1180)$ \\
\hline $\begin{array}{l}\text { Household head: high level of } \\
\text { education }\end{array}$ & $0.4915^{* *}(0.2055)$ & $0.3960(0.3158)$ & $0.3037^{*}(0.1464)$ \\
\hline $\begin{array}{l}\text { Household head: age } 30- \\
50 \text { years }\end{array}$ & $0.1144(0.0855)$ & $0.4853(0.7518)$ & $0.0716(0.0812)$ \\
\hline $\begin{array}{l}\text { Household head: age over } \\
50 \text { years }\end{array}$ & $0.1419(0.1906)$ & $0.5444(0.7585)$ & $0.1789(0.1358)$ \\
\hline Size of the household & $0.0179(0.0284)$ & $0.0605(0.0430)$ & $0.0341(0.0276)$ \\
\hline $\begin{array}{l}\text { Number of children in the } \\
\text { household }\end{array}$ & $-0.08219(0.0615)$ & $-0.4330^{* * *}(0.1059)$ & $-0.2313^{* * *}(0.0651)$ \\
\hline Urban household & $0.7318^{* * *}(0.1782)$ & $0.9429^{* * *}(0.2389)$ & $0.8188^{* * *}(0.1721)$ \\
\hline Expenditure quintile 2 & $0.4840^{* * *}(0.1136)$ & $0.5003^{* * *}(0.1728)$ & $0.4814^{* * *}(0.1093)$ \\
\hline Expenditure quintile 3 & $0.7781^{* * *}(0.1202)$ & $0.8602^{* * *}(0.1928)$ & $0.8241^{* * *}(0.1138)$ \\
\hline Expenditure quintile 4 & $1.2640^{* * *}(0.1202)$ & $1.2404^{* * *}(0.2104)$ & $1.2657^{* * *}(0.1251)$ \\
\hline Expenditure quintile 5 (top) & $1.6384^{* * *}(0.1528)$ & $2.0827^{* * *}(0.2771)$ & $1.8289^{* * *}(0.1559)$ \\
\hline Year $(1998=1)$ & & & $-0.1592(0.1145)$ \\
\hline $\begin{array}{l}\text { Number of Observations } \\
2,054 \text { households }\end{array}$ & 4,659 children & 4,395 children & 9,054 children \\
\hline$R^{2}$ & 0.1065 & 0.1590 & 0.1250 \\
\hline
\end{tabular}

Notes: Equality of coefficient between 1993 and 1998 is rejected for: Number of children in the household (coeff. -0.35 ; SE 0.12; $t .-2.84$ ); Age (coef. 1.58; SE 0.53; $t-2.97$ ); Age squared (coeff. 0.07; SE 0.02; $t .3 .02$ ). Significance levels $=* * *(p<0.01), * *(p<0.05), *(p<0.1)$; Cluster-Robust Standard Errors in brackets.

methods, allowing for unobserved fixed effects that may be correlated with the decision to migrate and, therefore, with international and domestic remittances, help solving this problem. Fixed-effects estimation methods seem to be a suitable way to correctly estimate the relative importance of domestic versus international remittances for children's outcomes.

Table 7 presents the results of the two-sided censoring model with fixed effects estimated on the panel data. 
The most striking result is that only the domestic component of remittances appears to have significant positive effects for child well-being: children are less likely to work and more likely attend school if the household receives domestic remittances. This is in contrast with our cross-sectional results and with much of previous research on the subject.

A possible interpretation of this result might be that international migrants find it more difficult to maintain close relationships with their families, since their visits to their countries of origin are infrequent. Hence, the negative side effects determined by lack of parental care for the children left behind might outpace the benefits generated by receiving international remittances.

From the econometric point of view, the result emerging from the cross-sectional analysis may simply be due to the problem of omitted variables. International migrants and their families of origin are usually better-off and more educated than the average; thus, the positive and significant impact of international remittances observed in the cross section is likely to be the result of unobservable factors. In fact, receiving remittances may be endogenous: recipient households may have

TABLE 7

Household Child Labor and Schooling. Two-Sided Censoring Model with Fixed Effects

\begin{tabular}{lrr}
\hline \hline & \multicolumn{1}{c}{$\begin{array}{c}\text { Child labor } \\
\text { Coefficients (SE) }\end{array}$} & \multicolumn{1}{c}{$\begin{array}{c}\text { Schooling } \\
\text { Coefficients (SE) }\end{array}$} \\
\hline Log of the value of domestic remittances & $-0.0161^{* *}(0.0073)$ & $0.0302^{*}(0.0173)$ \\
Log of the value of international remittances & $-0.0099(0.0143)$ & $0.0125(0.0192)$ \\
Proportion of male children in the household & $-0.0932(0.0781)$ & $0.4797^{* * *}(0.1821)$ \\
Average age of children in the household & $0.2572^{* * *}(0.0906)$ & $0.0228(0.2505)$ \\
Average age of children in the household squared & $-0.005(0.0041)$ & $-0.0117(0.0112)$ \\
Recipient is migrant's parent or grandparent & $0.1339(0.1291)$ & $-0.2941(0.2067)$ \\
Gender of the household head & $-0.1167(0.0929)$ & $0.4079(0.2840)$ \\
Household head: low level of education & $-0.0811^{* *}(0.0382)$ & $-0.0387(0.1074)$ \\
Household head: medium level of education & $-0.1367^{* *}(0.0576)$ & $-0.0469(0.1519)$ \\
Household head: high level of education & $-0.2251(0.0875)$ & $-0.0333(0.2082)$ \\
Household head: age 30-50 years & $-0.0699(0.0547)$ & $0.003(0.0968)$ \\
Household head: age over 50 years & $-0.1258(0.0984)$ & $-0.0074(0.1629)$ \\
Size of the household & $0.0056(0.0211)$ & $0.0649(0.0495)$ \\
Number of children in the household & $0.068^{* * *}(0.0259)$ & $-0.3471^{* * *}(0.0702)$ \\
Urban household & $-0.1661(0.2989)$ & $0.6994(0.5949)$ \\
Expenditure quintile 2 & $-0.0152(0.0466)$ & $0.0570(0.1130)$ \\
Expenditure quintile 3 & $-0.0598(0.0589)$ & $0.1415(0.1192)$ \\
Expenditure quintile 4 & $-0.077(0.0792)$ & $0.3120^{*}(0.1767)$ \\
Expenditure quintile 5 (top) & $0.078(0.1161)$ & $-0.0373(0.2377)$ \\
Year (1998 = 1) & $-0.132^{* *}(0.0555)$ & $-0.0018(0.1172)$ \\
\hline Notes: Num & &
\end{tabular}

Notes: Number of Observations: 4,108. Number of Groups: 2,054. Child Labor: Frac. Cen. Above $\left(Y_{i t}=0\right): 0.60$; Frac. Cen. Below $\left(Y_{i t}=1\right): 0.13$. Schooling: Frac. Cen. Above $\left(Y_{i t}=0\right): 0.29$; Frac. Cen. Below $\left(Y_{i t}=1\right): 0.51$. Significance levels $=* * *(p<0.01), * *(p<0.05), *(p<0.1)$. Cluster-Robust Standard Errors in brackets. 
characteristics correlated to receiving remittances that make them more likely to send/not to send their children to school/to work. This may be more likely in households where some members have migrated abroad, and where overseas migration was mainly driven by political factors, as in the case of Vietnam. Our two-sided regression method with fixed-effects enables us to control for the time-invariant unobserved characteristics and to tackle the endogeneity problem of the migration decision.

As for the other significant coefficients, schooling appears to be more probable for males and work more probable for older children.

Consistent with the descriptive evidence of Table 3 and the crosssectional results, an increasingly large number of children in the household appears to produce a significant detrimental effect on both our measures of child well-being. In order to understand whether this effect is more pronounced for girls than boys or the other way around, we have also estimated the model by gender. In this case, the dependent variables become the proportions of male/female attending school/working over the total number of males/females in the household. Table 8 reports the estimated coefficients of Number of children in the household. As for the positive and significant effect on child labor, the number of siblings in the household does not seem to have a clear gender-specific pattern over time and in the panel analysis. Instead, as far as schooling is concerned, the negative effect appearing in Table 7 is driven by boys. This is an interesting result that makes Vietnam quite different from other developing countries where girls experience more difficulties than boys. As far as the impact of remittances is concerned, no specific gender-specific pattern can be derived, also because the reduction in the number of observations when estimating by gender makes the number of household receiving remittances too low for statistical precision.

As far as household indicators of education are concerned, the more educated the household head, the lower probability of the average child going to work, but increasing education levels of the household head have no significant impact on children's probability to attend school. At variance with the cross-sectional results, although the coefficients associated with the household expenditure quintiles bear the expected signs, only the coefficient of the fourth quintile shows a significant positive impact on child schooling. Also in this case, controlling for the fixed effects has significantly changed the results, confirming household expenditure to be a poorer indicator of household economic status with respect to household total income. 
TABLE 8

Coefficients of Number of Children in the Household by Gender

\begin{tabular}{|c|c|c|c|}
\hline \multicolumn{2}{|c|}{ Child labor } & \multicolumn{2}{|c|}{ Schooling } \\
\hline Males & Females & Males & Females \\
\hline & & & \\
\hline $\begin{array}{l}0.1607 * * * \\
(0.0567)\end{array}$ & $\begin{array}{l}0.1344 * * \\
(0.0571)\end{array}$ & $\begin{array}{c}-0.1730 * * * \\
(0.0524)\end{array}$ & $\begin{array}{r}-0.0265 \\
(0.0533)\end{array}$ \\
\hline $\begin{array}{c}0.1277^{*} \\
(0.0708)\end{array}$ & $\begin{array}{l}0.1725^{* * *} \\
(0.0694)\end{array}$ & $\begin{array}{c}-0.2397 * * * \\
(0.066)\end{array}$ & $\begin{array}{r}-0.0973 \\
(0.0633)\end{array}$ \\
\hline $\begin{array}{l}0.02619^{* *} \\
(0.0116)\end{array}$ & $\begin{array}{c}0.0207^{*} \\
(0.0115)\end{array}$ & $\begin{array}{c}-0.0481 * * * \\
(0.0129)\end{array}$ & $\begin{array}{r}-0.0045 \\
(0.0128)\end{array}$ \\
\hline
\end{tabular}

Note: The cross-sectional coefficients are estimated with bilogit. Since the two-sided censoring model did not converge, the panel coefficients are estimated with the linear probability model with fixed effects. All other control variables of Tables 5-7 are included. Significance levels $=* * *(p<0.01), * *(p<0.05), *(p<0.1)$. Standard errors in parenthesis.

\section{CONCLUDING REMARKS}

In the large body of literature dealing with the increasing importance of remittance flows for developing countries, the number of studies that investigate the specific impact of domestic and international remittances on child well-being remains limited. We have attempted to explore this crucial relationship by separately taking into account the effects of remittances on child labor and on school attendance. The analysis of the difference between the effects of domestic and international remittances, separating their respective values, has highlighted the greater importance of internal flows of remittances for child well-being.

The largest part of the existing literature on this subject is based on cross-sectional data. The evidence emerging from the majority of these analyses seems to indicate that remittances matter for child well-being, but international remittances matter more than domestic remittances. Therefore, our main objective was to ascertain whether this result is confirmed when unobservable fixed effects are taken into account.

Using panel data from the 1993 and 1998 VLSS, we have compared the results derived from our cross-sectional analysis with those of our panel analysis. We have employed an estimation procedure that focuses on the average characteristics of all children belonging to each household, thus generating an average representative child at the household level. Our findings show, in line with the literature, that children belonging to recipient households are less likely to be sent to work and more likely to 
attend school than children who live in households where this source of income is absent.

However, although at the cross-sectional levels receiving international remittances appears to have a stronger effect than receiving domestic remittances, this difference is reversed in our panel analysis. After controlling for time-invariant unobservable characteristics with a fixed-effects model, domestic remittances are found to be the only significant inflow of migrants' money to reduce child labor and increase school attendance. In line with the evidence found in studies on the negative effects of parental absence on the well-being of children, we attribute the result of the insignificant effect of international remittances to the lack of parental care for children left behind in migrants' households of origin. Internal migrants, unlike international migrants, are likely to preserve a relatively close relationship with their families of origin, thus maintaining control over their children's welfare and the way in which remittances are spent.

On the econometric side, the significant impacts of international remittances observed in the cross-sectional analyses were probably due to unobserved household factors. These factors were removed in the panel analysis which, we believe, achieves a better understanding of the complex relationship between receiving remittances and children's well-being.

The importance of facilitating labor movement, especially within national borders, appears to be the main policy implication stemming from our findings. When people are free to migrate between provinces, often from rural to urban areas, they can sustain the welfare of their children left behind by sending domestic remittances while continuing to have a good oversight of their activities. At the same time, the highlighted downsides related to international migration should be tackled with a set of policies aimed at providing care to children with migrant parents living abroad. This would make the impacts of international remittances more effective and beneficial for children's well-being.

\section{REFERENCES}

Acosta, P.

2011 "School Attendance, Child Labor, and Remittances From International Migration in El Salvador." Journal of Development Studies 47(6):913-36.

Adams, R. H.

2011 "Evaluating the Economic Impact of International Remittances On Developing Countries Using Household Surveys: A Literature Review." Journal of Development Studies 47(6):809-28. 
Adams, R., and A. Cuecuecha

2010 "Remittances, Household Expenditure and Investment in Guatemala." World Development 38(11):1626-41.

2013 "The Impact of Remittances on Investment and Poverty in Ghana." World Development 50:24-40.

Alan, S., B. E. Honore, L. Hu, and S. Leth-Petersen

2014 "Estimation of Panel Data Regression Models With Two-Sided Censoring or Truncation." Journal of Econometric Methods 3(1):1-20.

Amuedo-Dorantes, C., and S. Pozo

2010 “Accounting for Remittance and Migration Effects on Children's Schooling." World Development 38(12):1747-59.

Antman, F.

2012 "Gender, Educational Attainment and the Impact of Parental Migration on Children Left Behind.” Journal of Population Economics 25(4):1187-214.

Basu, K., and P. H. Van

1998 "The Economics of Child Labor." American Economic Review 88(3):412-27.

Cox Edwards, A., and M. Ureta

2003 "International Migration, Remittances, and Schooling: Evidence From El Salvador." Journal of Development Economics 72:429-61.

De Carvalho Filho, I. E.

2012 "Household Income as a Determinant of Child Labor and School Enrollment in Brazil: Evidence From a Social Security Reform." Economic Development and Cultural Change 60(3):399-435.

Dimova, R., G. Epstein, and I. Gang

2011 "Migration, Transfers, and Child Labor." IZA Discussion Papers No. 5641. Bonn: Institute for the Study of Labor (IZA).

Dollar, D.

2004 "Reform, Growth, and Poverty." In Economic Growth, Poverty and Household Welfare in Vietnam, edited by P. Glewwe, N. Agrawal, and D. Dollar, 29-51. Washington, DC: World Bank.

Edmonds, E.

2005 “Does Child Labor Decline With Improving Economic Status?” Journal of Human Resources 40(1):99.

2006 "Understanding Sibling Differences in Child Labor." Journal of Population Economics 19:795-821.

2008 "Child Labor." In Handbook of Development Economics ch. 57. Amsterdam: Elsevier.

$\longrightarrow$, and C. Turk

2004 "Child Labor in Transition in Vietnam." In Economic Growth, Poverty and Household Welfare in Vietnam, edited by P. Glewwe, N. Agarwal, and D. Dollar, 50550. Washington, DC: World Bank.

Epstein, G. S., and N. Kahana

2008 "The Effect of Emigration on Child Labor." Economics Letters 99(3):545-8.

Giannelli, G. C., and L. Mangiavacchi

2010 "Children's Schooling and Parental Migration: Empirical Evidence on the 'LeftBehind' Generation in Albania." Labour 24(1):76-92. 
Glewwe, P., S. Koch, and B. L. Nguyen

2004 "Child Nutrition, Economic Growth, and The Provision Of Health Care Services In Vietnam." In Economic Growth, Poverty and Household Welfare in Vietnam, edited by P. Glewwe, N. Agrawal, and D. Dollar, 351-89. Washington, DC: World Bank.

Honoré, B. E., and J. L. Powell

1994 "Pairwise Difference Estimators of Censored and Truncated Regression Models." Journal of Econometrics 64(1-2):241-78.

Joseph, G., and S. Plaza

2010 "Impact of Remittances on Child Labor in Ghana." IZA Conference Paper s6083.

Khan, N. C., D. le Tuyen,, T. X. Ngoc, P. H. Duong, and H. Khoi

2007 "Reduction in Childhood Malnutrition in Vietnam From 1990 to 2004." Asia Pacific Journal of Clinical Nutrition 16(2):274-8.

McKenzie, D., and H. Rapoport

2011 "Can Migration Reduce Educational Attainments? Depressing Evidence From Mexico." Journal of Population Economics 24(4):1331-58.

Nguyen, V. C.

2009 "Impacts of International and Internal Remittances on Household Welfare: Evidence From Vietnam." Asia-Pacific Development Journal 16(1):59-92.

Rapoport, H., and F. Docquier

2006 "The Economics of Migrants' Remittances." Handbook on the Economics of Giving, Reciprocity and Altruism 2:1135-1198 Amsterdam: Elsevier.

World Bank

2000 Vietnam Living Standard Survey (VNLSS), 1992-1993: Basic Information. Poverty and HR Division Report. Washington, DC: World Bank.

2001 Vietnam Living Standard Survey (VLSS), 1997-1998: Basic Information. Poverty and HR Division Report. Washington, DC: World Bank.

Yang, D.

2008 "International Migration, Remittances and Household Investment: Evidence From Philippine Migrants' Exchange Rate Shocks.” The Economic Journal 118(528):591630. 